\title{
Long-Read Amplicon Sequencing of Nitric Oxide Dismutase (nod) Genes Reveal Diverse Oxygenic Denitrifiers in Agricultural Soils and Lake Sediments
}

\author{
Baoli Zhu ${ }^{1}$ (D) Zhe Wang ${ }^{1} \cdot$ Dheeraj Kanaparthi ${ }^{1} \cdot$ Susanne Kublik ${ }^{2} \cdot$ Tida Ge $^{3} \cdot$ Peter Casper $^{4} \cdot$ Michael Schloter $^{2}$. \\ Tillmann Lueders ${ }^{1}$
}

Received: 13 November 2019 / Accepted: 2 January 2020 / Published online: 27 January 2020

(C) The Author(s) 2020

\begin{abstract}
Microorganisms play an essential role in nitrogen cycling and greenhouse gas emissions in soils and sediments. The recently discovered oxygenic denitrifiers are proposed to reduce nitrate and nitrite via nitric oxide dismutation directly to $\mathrm{N}_{2}$ and $\mathrm{O}_{2}$. So far, the ecological role of these microbes is not well understood. The only available tool for a targeted study of oxygenic denitrifiers is their respective maker gene, nitric oxide dismutase (nod). Here, we established the use of PacBio long-read sequencing of nod gene amplicons to study the diversity and community structure of oxygenic denitrifiers. Two distinct sets of environmental samples, agricultural soil and lake sediment, were investigated as examples. The circular consensus sequences ( $c$ a $1.0 \mathrm{~kb}$ ) obtained covered most substitution characteristic of NO dismutase and allowed for reliable classification of oxygenic denitrifiers. Distinct nod gene pools and community structure were revealed for the different habitats, with most sequence types affiliated to yet unidentified environmental nod lineages. The abundance of nod genes ranged $2.2 \times 10^{6}-3.2 \times 10^{7}$ gene copies $^{-1}$ soil or sediment, accounting for up to $3 \%$ of total bacterial $16 \mathrm{~S}$ rRNA gene counts. This study indicates that nod-gene-targeted long-read sequencing can be a powerful tool for studying the ecology of these novel microbes, and the results also suggest that oxygenic denitrifiers are prevalent and abundant in different terrestrial samples, where they could play an important, but yet overlooked role in nitrogen transformations.
\end{abstract}

Keywords PacBio SMRT sequencing · Oxygenic denitrification · Oxygenic denitrifier · Nitric oxide dismutase (Nod)

Electronic supplementary material The online version of this article (https://doi.org/10.1007/s00248-020-01482-0) contains supplementary material, which is available to authorized users.

Baoli Zhu

baoli.zhu@uni-bayreuth.de

Tillmann Lueders

tillmann.lueders@uni-bayreuth.de

1 Chair of Ecological Microbiology, Bayreuth Center of Ecology and Environmental Research (BayCEER), University of Bayreuth, Dr.-Hans-Frisch-Straße 1-3, 95440 Bayreuth, Germany

2 Research Unit for Comparative Microbiome Analysis, Helmholtz Zentrum München, Neuherberg, Germany

3 Key Laboratory of Agro-ecological Processes in Subtropical Region \& Changsha Research Station for Agricultural and Environmental Monitoring, Institute of Subtropical Agriculture, Chinese Academy of Sciences, Changsha, Hunan, China

4 Leibniz-Institute of Freshwater Ecology and Inland Fisheries, Stechlin, Germany
Microbes play important roles in biogeochemical cycling of nitrogen $(\mathrm{N})$, which is often a limiting nutrient for agricultural production. Fertilization shapes soil microbial diversity and community structure, while microbes in turn affect the fate of applied fertilizers [1]. Microorganisms have been recognized as the main drivers for nitrogen loss and soil $\mathrm{N}_{2} \mathrm{O}$ emission, which constitutes the dominant $\mathrm{N}_{2} \mathrm{O}$ source, emitting annually over $4 \mathrm{Tg} \mathrm{N}_{2} \mathrm{O}-\mathrm{N}$ into the atmosphere [2]. Various microbial groups involved in $\mathrm{N}$ cycling have been studied (e.g. [3]), typically using different activity-based or marker gene-based approaches. Well-established primer systems and PCR assays are available for many marker genes of microbial $\mathrm{N}$ cycling, and have been extensively utilized in nextgeneration sequencing studies (e.g. [4]).

Oxygenic denitrification is a recently proposed $\mathrm{N}$ transforming process, where nitric oxide (NO) is directly disproportionated into $\mathrm{N}_{2}$ and $\mathrm{O}_{2}$, thus avoiding the powerful greenhouse gas, $\mathrm{N}_{2} \mathrm{O}$ emissions. The reaction is catalyzed by a NO dismutase (Nod) [5]. The use of nod gene as a marker for 
Table 1 Soil samples and lake sediments analyzed in this study and their key geochemical characteristics

\begin{tabular}{|c|c|c|c|c|c|c|c|}
\hline Sample type & Designation & Explanation & $\mathrm{pH}$ & Total nitrogen & $\begin{array}{l}\mathrm{SOC} / \\
\mathrm{DOC}\end{array}$ & Trophic status & Reference \\
\hline \multirow{4}{*}{ Agriculture soil } & $\mathrm{CF}$ & Soil received chemical fertilizer & 5.5 & $1.9 \mathrm{~g} / \mathrm{kg}$ & $17.5 \mathrm{~g} / \mathrm{kg}$ & & \multirow[t]{4}{*}[13]{} \\
\hline & CF-straw & Soil received chemical fertilizer and straw & 6.0 & $2.6 \mathrm{~g} / \mathrm{kg}$ & $25.5 \mathrm{~g} / \mathrm{kg}$ & & \\
\hline & CF-manure & Soil received chemical fertilizer and manure & 5.7 & $2.2 \mathrm{~g} / \mathrm{kg}$ & $22.0 \mathrm{~g} / \mathrm{kg}$ & & \\
\hline & control & Soil received no extra fertilizers & 5.4 & $1.8 \mathrm{~g} / \mathrm{kg}$ & $18.3 \mathrm{~g} / \mathrm{kg}$ & & \\
\hline \multirow[t]{4}{*}{ Lake sediment* } & Stechlin & Deep, dimictic Lake Stechlin, Germany & 7.8 & $0.2(\mathrm{mg} / \mathrm{l})$ & $4.3 \mathrm{mg} / 1$ & meso-oligotrophic & {$[14]$} \\
\hline & Dagow & Lake Dagow, Germany & 8.1 & $0.5(\mathrm{mg} / \mathrm{l})$ & n.d & eutrophic & {$[11]$} \\
\hline & SW & South-west basin of Lake Grosse Fuchskuhle & 4.5 & $1.0(\mathrm{mg} / \mathrm{l})$ & $3205 \mathrm{mg} / 1$ & dystrophic & \multirow[t]{2}{*}[12]{} \\
\hline & $\mathrm{NE}$ & North-east basin of Lake Grosse Fuchskuhle & 5.8 & $1.7(\mathrm{mg} / \mathrm{l})$ & $16.4 \mathrm{mg} / 1$ & dystrophic & \\
\hline
\end{tabular}

* Data are the average of the bottom water column in March-May 2016

n.d no data
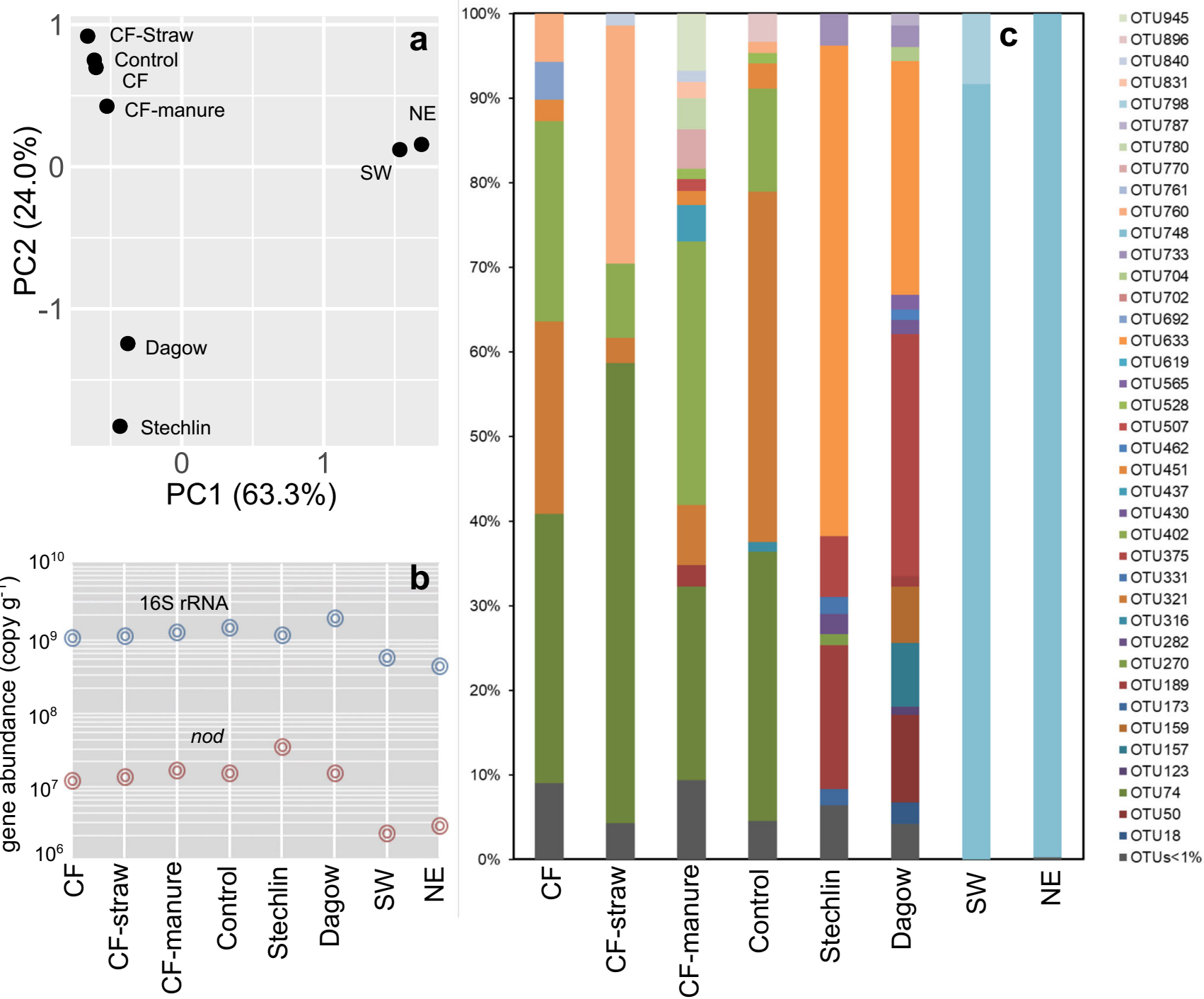

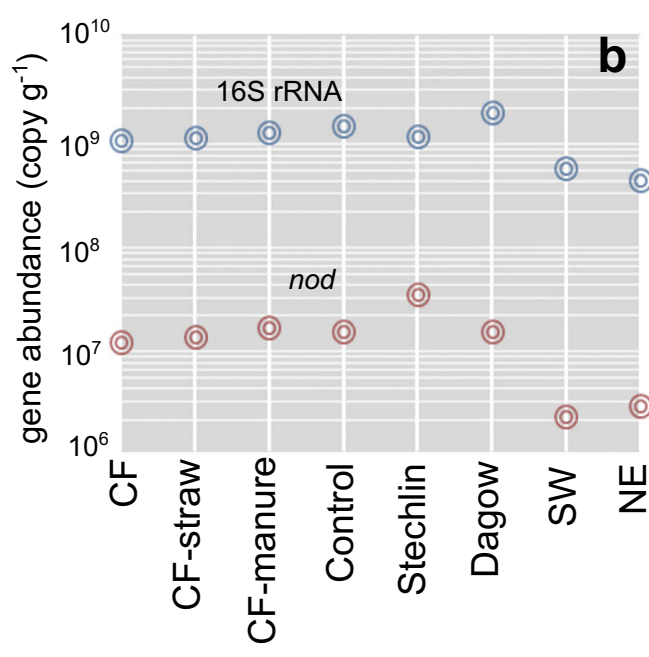

Fig. 1 a Principal component analysis (PCA) of the oxygenic denitrifier community in all samples, based on the occurrence and relative abundance of all nod OTUs. b The abundance of total bacteria and oxygenic denitrifiers in different samples as quantified by qPCR targeting $16 \mathrm{~S}$
rRNA and nod genes, respectively. c nod community in different environments. OTU was categorized based on a $90 \%$ similarity of $c a .1 .0 \mathrm{~kb}$ nod gene fragments. The sample designations are the same as in Table 1 
oxygenic denitrifiers was recently established [6,7], with which, evidence was obtained suggesting that oxygenic denitrifiers could be widespread and phylogenetically diverse $[6$, 8]. However, the high diversity inferred from nod genes provided no clue to the actual identities of these novel oxygenic denitrifiers [6]. So far, the identification of oxygenic denitrifiers and analysis of their community structures solely depend on the length and quality of obtained nod sequences. In previous studies, long nod sequences were obtained via laborious and low-throughput Sanger sequencing, since next-generation sequencing often generates short reads. Recently, PacBio SMRT sequencing provides access to high-throughput longread environmental sequence data, but has been applied mostly to metagenomics and full-length 16S rRNA gene analysis (e.g. $[9,10])$. Here, we provide a first proof-of-principle for the use of nod-targeted PacBio sequencing to study the distribution and community structure of oxygenic denitrifiers in terrestrial systems. Soils, especially under $\mathrm{N}$ fertilization, are known as hotspots of microbial $\mathrm{N}$ cycling; thus, agricultural soils undergoing different long-term fertilization regimes were chosen as example environments. To demonstrate the wide applicability of this approach, several sediment samples from lakes with different trophic status were also queried (Table 1).

Soil from the top layer $(0-10 \mathrm{~cm})$ of several agricultural fields with and without long-term fertilizations in Ning-Xiang, China [13], and sediments from a meso-oligotrophic, an eutrophic and a dystrophic lake in Germany [11, 12, 14], were sampled (Table 1). The abundance of nod genes and bacterial 16S rRNA was quantified by qPCR, representing respective measure of putative oxygenic denitrifiers and total bacteria in these samples. In all soils, the respective counts of oxygenic denitrifiers $\left(1.12 \times 10^{7}-1.54 \times 10^{7}\right.$ copy $n o d \mathrm{~g}^{-1}$ soil $)$ and total bacteria (from $9.75 \times 10^{8}$ to $1.37 \times 10^{9}$ copies $16 \mathrm{~S}_{\mathrm{rRNA} \mathrm{g}}{ }^{-1}$ soil) were similar (Fig. 1b), resulting in a rather comparable relative abundance of nod genes at $1-1.3 \%$. nod gene abundance was in a similar range as that of nirK and nirS genes observed in other soil ecosystems [15, 16], indicating that oxygenic denitrifier abundance can be similar to that of conventional denitrifiers. In contrast to conventional nitrifying and denitrifying microbes [16, 17], oxygenic denitrifier abundance examined here seemed not significantly influenced by nitrogen fertilization. While nod gene abundances varied more widely in lake sediments, from $2.17 \times 10^{6} \mathrm{~g}^{-1}$ sediment in Lake Grosse Fuchskuhle to $3.2 \times 10^{7} \mathrm{~g}^{-1}$ sediment in Lake Stechlin, accounting for about $0.4-3.0 \%$ of total bacterial number (Fig. 1b).

With PacBio SMRT sequencing, long nod amplicons (ca. $1.0 \mathrm{~kb}$ ) from all samples were sequenced. Details on the procedure and data analysis are provided in the supplementary information (SI). In total, 61 nod OTUs with at least 50 sequences were classified based on $90 \%$ similarity on nucleotide level [7]. Representative sequences were used for phylogenetic analysis, revealing that almost all OTUs detected in this study were related to previously reported nod lineages [6], with most of them belonging to the nod "Aquifer cluster," 5 OTUs in the "NC10 cluster," and 1 OTU in the "Reactor cluster 1" (Fig. 2). All representative sequences of these OTUs that related to nod clusters possessed previously identified Nod-characteristic residual substitutions (Fig. 3).

Overall nod gene pools appeared similar in the agriculture soils subjected to different fertilization regimes (Fig. 1a, c). However, the soil receiving both chemical fertilizer (CF) and manure harbored the highest nod diversity across all samples (Fig. 1c). Lake Stechlin and Lake Dagow sediments hosted a higher nod diversity compared with Lake Grosse Fuchskuhle (Fig. 1c), which was mostly dominated by OTU748. Possibly, this was related to their different $\mathrm{pH}$ and trophic status (Table 1). Principal component analysis (PCA) of nod composition clearly supported that distinct oxygenic denitrifier communities were present in agriculture soils and lake

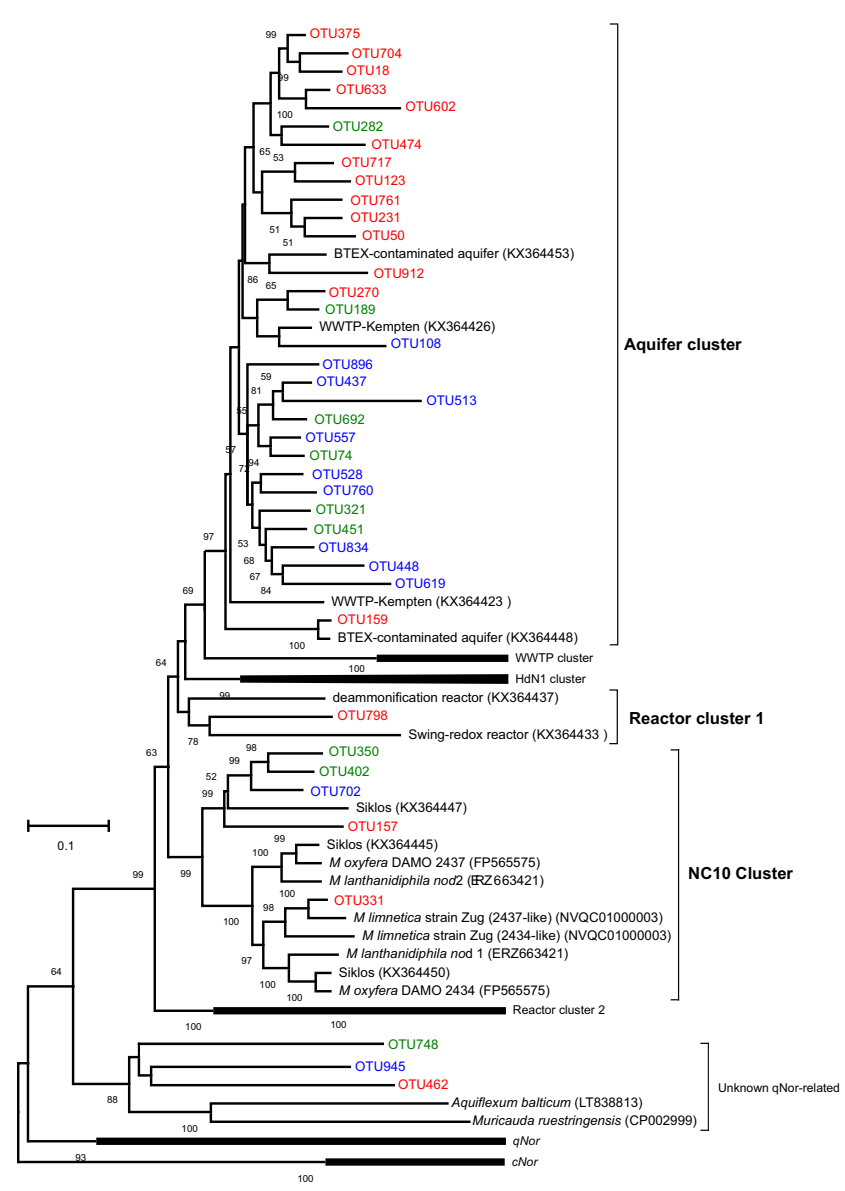

Fig. 2 Bootstrapped neighbor-joining phylogeny of nod OTU representative nucleotide sequences. Bootstrap support (1000 replicates) greater than $50 \%$ is indicated at the nodes. Nod clusters (same as proposed in [6]) containing soil and lake nod OTUs are shown in bold. OTUs only detected in soil are shown in blue, lake-specific OTUs in red, and OTUs comprising sequences from both soil and lake sediment are shown in green. The scale bar represents $10 \%$ nucleotide sequence divergence. The phylogeny was calculated in MEGA-X 

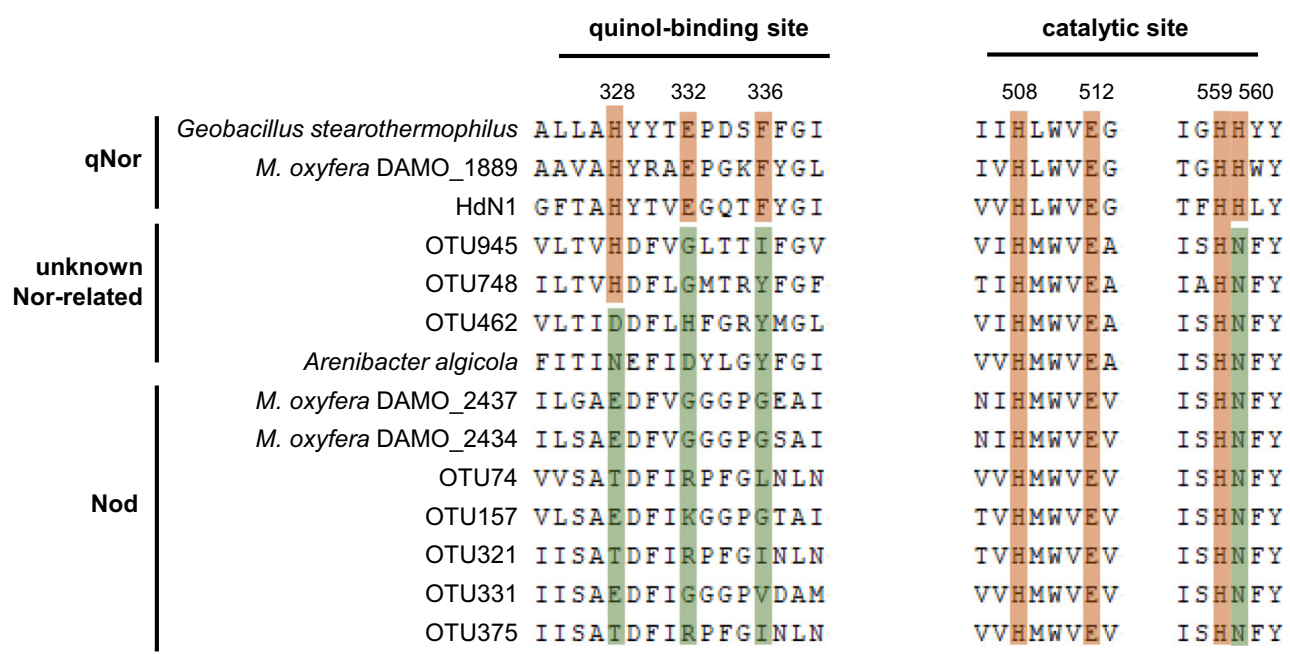

Fig. 3 Multiple-sequence alignment of Nod representatives (deduced from nod gene sequences) and qNor enzymes around the quinolbinding site and the catalytic site of qNor. The conserved residues for quinol binding and catalytic functioning in qNor are highlighted in orange, whereas substitutions at these sites in Nod and unknown Norrelated sequences are shown in green. Due to the length limit of the

sediments (Fig. 1a). Only a limited number of OTUs were shared between soils and sediments, yet habitat-specific OTUs were evident in both soil and lakes, and they tended to be closely placed within the "Aquifer cluster" on the phylogenetic tree (Fig. 2), such as OUT74 was highly abundant in all soils but was not detected in sediments, suggesting that the environment largely determines the composition of nod gene pools.

Nevertheless, three OTUs, OTU462, 748, and 945, clustered more closely to the "unknown-qNor-related" sequences [6] in phylogenetic analysis (Fig. 2). Although OTU462 sequences also showed the presumed characteristic residual substitutions for Nod (Fig. 3), the functional connotation of this gene lineage must be interpreted with caution. This suggests that both phylogenetic and residual substitution analysis are necessary for identifying environmental nod sequences, a result clearly facilitated by the long sequences obtained from PacBio SMRT sequencing.

Taken all together, the results indicated that agriculture soils harbor diverse and abundant oxygenic denitrifiers, which have been overlooked in the past. Low pH in Lake Grosse Fuchskuhle seemed to disfavor oxygenic denitrifiers. Moreover, functionalgene-targeted long-read sequencing was proven to be a powerful tool for analyzing novel microbial guilds in the environment, and it will allow us to gain better insights into the influencing environmental factors that shape the distribution and community structure of oxygenic denitrifiers and uncover their ecological roles in $\mathrm{N}$ cycling in natural habitats.

Acknowledgments We thank Gabriele Barthel (Helmholtz Zentrum München) for her expert technical assistance in the sequencing workflow. recovered Nod sequences, the functional sites shown here are incomplete. Signature residual mutations are observed in soil and lake Nod sequences as well. The residual numbering was according to the Geobacillus stearothermophilus qNor (AB450501). The alignment was generated with ClustalW in MEGA-X

Funding Information Open Access funding provided by Projekt DEAL. This research was funded by the European Research Council (ERC) under the European Union's Seventh Framework Program (FP7/20072013), grant agreement 616644 (POLLOX) to TL. TG was supported by the National Natural Science Foundation of China (41430860) and the Innovation Groups of Natural Science Foundation of Hunan Province (2019JJ10003).

Open Access This article is licensed under a Creative Commons Attribution 4.0 International License, which permits use, sharing, adaptation, distribution and reproduction in any medium or format, as long as you give appropriate credit to the original author(s) and the source, provide a link to the Creative Commons licence, and indicate if changes were made. The images or other third party material in this article are included in the article's Creative Commons licence, unless indicated otherwise in a credit line to the material. If material is not included in the article's Creative Commons licence and your intended use is not permitted by statutory regulation or exceeds the permitted use, you will need to obtain permission directly from the copyright holder. To view a copy of this licence, visit http://creativecommons.org/licenses/by/4.0/.

\section{References}

1. Leff JW, Jones SE, Prober SM, Barberán A, Borer ET, Firn JL, Stanley Harpole W et al (2015) Consistent responses of soil microbial communities to elevated nutrient inputs in grasslands across the globe. Proc. Natl. Acad. Sci. 112(35):10967-10972. https://doi.org/ 10.1073/pnas.1508382112

2. Reay DS, Davidson EA, Smith KA, Smith P, Melillo JM, Dentener F, Crutzen PJ (2012) Global agriculture and nitrous oxide emissions. Nat. Clim. Chang. 2(6):410-416. https://doi.org/10.1038/nclimate1458

3. Levy-Booth DJ, Prescott CE, Grayston SJ (2014) Microbial functional genes involved in nitrogen fixation, nitrification and denitrification in forest ecosystems. Soil Biol. Biochem. 75(August):1125. https://doi.org/10.1016/j.soilbio.2014.03.021 
4. Zhang L, Jiang M, Ding K, Zhou S (2019) Iron oxides affect denitrifying bacterial communities with the NirS and NirK genes and potential $\mathrm{N} 2 \mathrm{O}$ emission rates from paddy soil. Eur. J. Soil Biol. 93(July):103093. https://doi.org/10.1016/j.ejsobi.2019.103093

5. Ettwig KF, Butler MK, Le Paslier D, Pelletier E, Mangenot S, Kuypers MM, Schreiber F, Dutilh BE, Zedelius J, de Beer D, Gloerich J, Wessels HJ, van Alen T, Luesken F, Wu ML, van de Pas-Schoonen KT, Op den Camp HJ, Janssen-Megens EM, Francoijs KJ, Stunnenberg H, Weissenbach J, Jetten MS, Strous M (2010) Nitrite-driven anaerobic methane oxidation by oxygenic bacteria. Nature 464:543-548

6. Zhu B, Bradford L, Huang S, Szalay A, Leix C, Weissbach M, Táncsics A, Drewes JE, Lueders T (2017) Unexpected diversity and high abundance of putative nitric oxide dismutase (Nod) genes in contaminated aquifers and wastewater treatment systems. Appl. Environ. Microbiol. 83(4):e02750-e02716. https://doi.org/10. 1128/AEM.02750-16

7. Zhu B, Wang J, Bradford LM, Ettwig K, Hu B, Lueders T (2019) Nitric oxide dismutase (nod) genes as a functional marker for the diversity and phylogeny of methane-driven oxygenic denitrifiers. Front. Microbiol. 10. https://doi.org/10.3389/fmicb.2019.01577

8. Zhang, Yanfen, Anzhou Ma, Wenzong Liu, Zhihui Bai, Xuliang Zhuang, and Guoqiang Zhuang. 2018. The occurrence of putative nitric oxide dismutase (nod) in an alpine wetland with a new dominant subcluster and the potential ability for a methane sink. Archaea (Vancouver, B.C.) 2018: 6201541. https://doi.org/10. 1155/2018/6201541

9. Callahan, Benjamin J., Joan Wong, Cheryl Heiner, Steve Oh, Casey M. Theriot, Ajay S. Gulati, Sarah K. McGill, and Michael K. Dougherty. 2019. High-throughput amplicon sequencing of the full-length 16S RRNA gene with single-nucleotide resolution. Nucleic Acids Research, July. https://doi.org/10.1093/nar/gkz569

10. Martijn J, Lind AE, Schön ME, Spiertz I, Juzokaite L, Bunikis I, Pettersson OV, Ettema TJG (2019) Confident phylogenetic identification of uncultured prokaryotes through long read amplicon sequencing of the 16S-ITS-23S rRNA operon. Environ. Microbiol. 21(7):2485-2498. https://doi.org/10.1111/1462-2920.14636
11. Conrad R, Claus P, Casper P (2009) Characterization of stable isotope fractionation during methane production in the sediment of a eutrophic lake, Lake Dagow, Germany. Limnol. Oceanogr. 54(2): 457-471. https://doi.org/10.4319/lo.2009.54.2.0457

12. Sepulveda-Jauregui A, Martinez-Cruz K, Lau M, Casper P (2018) Assessment of methane and carbon dioxide emissions in two subbasins of a small acidic bog lake artificially divided 30 years ago. Freshw. Biol. 63(12):1534-1549. https://doi.org/10.1111/fwb. 13182

13. Wang W, Liu Y, Tang H, Sun Z, Li B, Ge T, Jinshui W (2018a) Effects of long-term fertilization regimes on microbial biomass, community structure and activity in a paddy soil. Environ. Sci. 39(1):430-437 [in Chinese]

14. Selmeczy GB, Tapolczai K, Casper P, Krienitz L, Padisák J (2016) Spatial- and niche segregation of DCM-forming cyanobacteria in Lake Stechlin (Germany). Hydrobiologia 764(1):229-240. https:// doi.org/10.1007/s10750-015-2282-5

15. Assémien FL, Cantarel AAM, Florio A, Lerondelle C, Pommier T, Gonnety JT, Le Roux X (2019) Different groups of nitrite-reducers and N2O-reducers have distinct ecological niches and functional roles in West African cultivated soils. Soil Biol. Biochem. 129(February):39-47. https://doi.org/10.1016/j.soilbio.2018.11.003

16. Ouyang Y, Evans SE, Friesen ML, Tiemann LK (2018) Effect of nitrogen fertilization on the abundance of nitrogen cycling genes in agricultural soils: a meta-analysis of field studies. Soil Biol. Biochem. 127(December):71-78. https://doi.org/10.1016/j.soilbio. 2018.08.024

17. Wang F, Chen S, Wang Y, Zhang Y, Hu C, Liu B (2018b) Longterm nitrogen fertilization elevates the activity and abundance of nitrifying and denitrifying microbial communities in an upland soil: implications for nitrogen loss from intensive agricultural systems. Front. Microbiol. 9. https://doi.org/10.3389/fmicb.2018.02424

[Sequencing data are deposited at NCBI with SRA accession: PRJNA596123.] 